> Gi respons på artikler gjennom artiklenes kommentarfelt på tidsskriftet.no.

Innleggene publiseres fortløpende på Tidsskriftets nettside og et utvalg

av innleggene publiseres også i papirutgaven i spalten «Brev til redaktøren».

Redaksjonen forbeholder seg retten til å foreta redaksjonelle endringer.

Forfattere av vitenskapelige artikler har tilsvarsrett, jf. Vancouver-gruppens regler.

\section{Re: Når pasienten nekter blodoverføring}

I Tidsskriftet sto det nylig en kronikk om nekting av blodoverføring (1). Jeg forstår kronikken slik at den slår til lyd for en svekking av pasientrettighetene, og derfor vil jeg komme med noen kommentarer.

I kronikken står det: «Det er reist spørsmål ved om regelen i pasient- og brukerrettighetsloven § 4-9 heller må forstås slik at den som nekter å motta blod samtidig gir avkall på behandling der blodoverføring vil være det eneste riktige under gitte omstendigheter.» Det henvises her til jusprofessor Marit Halvorsen, som sier: «Grovt sagt, hvis man ønsker å bli operert, må man finne seg i å bli det på den måten som er medisinsk forsvarlig - altså eventuelt med blodoverføring» (2).

Mitt spesialfelt er lingvistikk og semantikk, og jeg kan ikke med min beste vilje se at det en gang er en antydning i lovteksten som gir grunnlag for denne tolkingen. Heller ikke i forarbeidene til loven er det noe som støtter den. Tvert imot strider tolkingen mot den retten alle har til å velge medisinsk behandling. Loven gir jo i klartekst pasienten rett til å avvise en behandling som legen foreslår, og en slik avvisning kan umulig innebære at man gir avkall på retten til å få en annen behandling.

I kronikken brukes uttrykkene «forsvarlig behandlingsmetode» og «faglig forsvarlig helsehjelp». Problemet er at disse oppfattes forskjellig av forskjellige leger, gitt ulik erfaring og kompetanse. En spørreundersøkelse viste at «norske anestesileger aksepterte et signifikant lavere hemoglobinnivå hos operasjonspasienter i 2002 sammenliknet med 1996 (...). Assistentlegene aksepterte en lavere hemoglobingrense enn overlegene, som igjen godtok en lavere grense enn avdelingsoverlegene» (3). Å henvise til lege artis som et kriterium for å overprøve pasientens nekting av blod er svært problematisk, siden begrepet har mange tolkinger. Selve kjernen i pasientrettighetsloven er retten til informert samtykke. Derfor, selv om uttrykket «forsvarlig behandlingsmetode» hadde hatt en entydig mening, noe det ikke har, ville ikke loven gitt en lege rett til å overprøve pasientens valg ved å si at dette valget var «uforsvarlig».

Da Jehovas vitners sykehuskontaktutvalg ble opprettet i 1990, og vi søkte etter samarbeidsvillige leger, hendte det flere ganger at en lege vegret seg for å utføre en operasjon fordi loven var uklar og han eller hun fryktet for eventuelle konsekvenser. Pasientrettighetsloven klargjorde situasjonen og løste dette problemet. Etter å ha holdt foredrag om blodløs behandling for mange hundre leger på sykehusavdelinger og svart på deres spørsmål og hørt deres kommentarer, er mitt klare inntrykk at det i dag er svært få problemer knyttet til behandling uten bruk av blod.

Forslaget om at den som nekter blod kan miste sin rett til medisinsk behandling når en lege sier at blod er nødvendig, vil både i nasjonal og global sammenheng virke meget urimelig. I utlandet finnes det sykehus som utelukkende utfører blodløs kirurgi og som ikke i noe tilfelle bruker blod $(5,6)$. Her er altså blodløs behandling lege artis. Det vil være inkonsekvent om norske pasienter skal tape retten til behandling når de velger en behandling som på mange sykehus i utlandet er standard prosedyre.

Pasientrettighetsloven tar på en utmerket måte både pasientenes og legenes rettigheter i betraktning. Den nye tolkingen av § 4-9 savner ethvert språklig grunnlag og bør derfor avvises.

Rolf J. Furuli

rolf.furuli@sf-nett.no
Rolf J. Furuli (f. 1942) er dr.art., pensjonert universitetslektor i semittisk lingvistikk og har vært et medlem av Jehovas vitners sykehuskontaktutvalg i Oslo i 24 år.

Ingen oppgitte interessekonflikter.

\section{Litteratur}

1. Bahus M, Førde R. Når pasienten nekter blodoverføring. Tidsskr Nor Legeforen 2014: 134: 850-1.

2. Halvorsen M. Pasienter som nekter behandling. Tidsskr Nor Lægeforen 2002; 122: $323-4$.

3. Reine PA, Kongsgaard UE, Smith-Erichsen N. Hemoglobingrenser og transfusjonspraksis blant norske anestesiologer. Tidsskr Nor Laegeforen 2004; 124 2610-2.

4. Center for Bloodless Medicine \& Surgery at Pennsylvania Hospital. www. pennmedicine.org/bloodless (15.8.2014).

5. Englewood Hospital and Medical Center. www.englewoodhospital.com/ ms bloodless home.asp (15.8.2014).

Engelsk oversettelse på www.tidsskriftet.no

\section{Re: Jakten på det utenomjordiske}

Etter at Ulvestad ikke klarte å bevise at helsemyndighetene ønsket å skremme folk til å vaksinere seg mot svineinfluensa, vil han nå heller diskutere om det var riktig å anbefale hele befolkningen vaksinering. Da må vi først rydde unna Ulvestads feilaktige forestillinger om anbefalingens grunnlag:

Kom anbefalingen fordi norske helsemyndigheter overdrev den forventede effekten av pandemien? Nei, risikovurderingen var meget god og nesten lik med Ulvestads post hoc-vurdering, slik jeg har vist $\mathrm{i}$ tidligere innlegg i denne debatten.

Kom anbefalingen fordi pandemiplanen (1) tilsa det? Nei, pandemiplanen beskriver mange mulige tiltak. Helsemyndighetene valgte bort flere av disse slik at responsen ble tilpasset pandemiens alvorlighet.

Var Norge nesten alene om en slik anbefaling? Nei, flertallet av EU/EØS-landene, USA og Canada ga samme anbefaling.

Kom anbefalingen som følge av «dårlig ledelse, lav grad av tillit og et anstrengt samarbeidsklima» hos helsemyndighetene? Nei, dette er fri fantasi.

Var anbefalingen unaturlig siden svineinfluensa ikke ble definert som en «allmennfarlig smittsom sykdom»? Nei, de fleste sykdommene som omfattes av vaksinasjonsprogrammet er heller ikke definert slik.

Visste helsemyndighetene «så godt som ingenting» om Pandemrix' effekt og bivirkninger? Nei, selvfølgelig ikke. Til grunn for markedsføringstillatelsen fra EUs legemiddelmyndighet lå omfattende dokumentasjonen (2). Anslag over vaksinens beskyttende effekt bygde på surrogatmålet antistoffnivå, slik det er vanlig ved influensavaksiner (3). Kunnskap om bivirkninger kom fra kliniske utprøvinger av Pandemrix med H5N1-viruset og med H1N1pdm09-viruset blant mange tusen personer. Den 23. oktober 2009 visste man også at inntil 70000 mennesker i Sverige var vaksinert uten uventede bivirkninger (4).

Blant europeiske og amerikanske fagfolk med eller uten beslutningsansvar fantes det flere syn på allmenn vaksinasjon mot svineinfluensa, til tross for at kunnskapsgrunnlaget om epidemien og vaksinene var det samme. Dette er selvsagt legitimt, og det kan skyldes at fagfolkene har vektet kunnskap og usikkerheter ulikt. Norske beslutningstakere la særlig vekt på at noen smittede faktisk ville få svært alvorlig sykdom (4). 